\title{
Leaf Quality and Usability: Theoretical Model I*
}

\author{
by T. C. Tso and G. B. Gori \\ Beltsville Agricultural Research Center, Agricultural Research Service, \\ United States Department of Agriculture, Beltsville, Maryland, U.S.A. \\ and \\ National Cancer Institute, United States Department of Health, Education, and Welfare, \\ Bethesda, Maryland, U.S.A.
}

\section{INTRODUCTION}

Product quality represents a balance of essential properties that meets the preference of a special group of consumers at a given time and location. Tobacco leaf quality is a relative term which varies greatly with human factors.

United States tobacco is generally accepted in trade circles around the world as the "best quality". It provides good "taste", which reflects an ideal balance of major chemical constituents, especially a proper ratio of nicotine to sugar for bright type tobacco. It also delivers a satisfying "aroma" and "flavor", which reflects adequately cultured, well-matured, ripe tobacco of grainy texture that is cured under correct conditions (1). Generally, tobacco quality factors involve criteria relating to: [a] Visible and otherwise detectable variables such as size, uniformity, color, texture, body, maturity, [b] Physical variables such as filling value, shatter resistance, and combustibility, and [c] Chemical variables such as nicotine, sugar, petroleum ether extracts, inorganics, organic acids; total volatile bases, and various nitrogenous fractions.

"Usability" represents the state of being usable without adverse effects. In the traditional sense, it relates to quality and, more importantly, to consumer acceptability. In the new sense, usability has an additional meaning - the relative safety or desirability to the consumers. When a product meets the requirements of both quality and desirability, it has high usability. Otherwise, it is considered to be of low usability. For example, certain chemical components may add to leaf quality by contributing to taste and aroma but may not be desirable because they contribute to the formation of undesirable smoke constituents. Under such conditions the problem of usability arises.

\footnotetext{
- Presented at the 16rth American Chemical Society Meeting, Ptiladelphia, Pa., USA, 1975.
}

\section{THE TRADITIONAL SMOKE QUALITY FACTORS}

Tobacco scientists have long attempted to establish several major criteria for easy identification of quality. Such criteria usually are centered on [a] strength (nicotine and other nitrogenous compounds), [b] aromaticity (resins, phenolics), [c] mildness (sugars, starch, oxalic acid), and [d] sharpness (cell membrane substances, ash constituents, citric acid) (1). Most studies, however, are limited to bright type tobacco.

Brüdkner (1936) derived a "quality index" that actually is a ratio of "summation of quality promoting substances" to "summation of quality restricting factors". According to his classification, sugar, stard, oxalic acid, tannins, and resins belong to the "promoting" category, cell membrane substance, ash, citric acid, nitrogenous compounds and $\mathrm{pH}$ value belong to the "restricting" category (2).

In 1958, Pyriki derived another formula for "quality index" (3) that is not too different from Brückner's. Pyriki's index is a ratio of "the sum of total reducing substances and resins and waxes" to "the sum of ash, nicotine, protein, ammonia, and other nitrogen".

The most simple criterion for judging organoleptic characteristics of bright tobacco is the sugar to nicotine ratio, as proposed by Coulson (4). A high ratio means a relatively mild smoke. He further suggested that the flavor of bright type tobacco resides in petroleum ether extracts of the leaf.

Many components are associated with flavor or aroma; mudh work has been published in this area. For example, Weybrew and Stephens (5) suggested that acetone and 2-butanone were positively related to leaf quality, and leaf maturity and curing appeared to elaborate volatile carbonyls (6). Many aldehydes and ketones were also reported to enhance flavor and aroma $(7,8)$. Stedman and Still (9) reported that isovaleric and $\beta$-methyl valeric acids may be used in blended cigarettes to provide the aroma of Oriental type tobacco. 


\section{THE CHANGING CONCEPT}

Since the release of the Smoking and Health Report in 1964 (10) and numerous subsequent findings, the basic concept of leaf quality should be re-oriented to meet the requirements of leaf usability. The most significant dhanges are demonstrated in the wide concern for the "tar" delivery level and in the use of the filtration system. The ultimate goal is to obtain a product that meets the quality criteria for consumer acceptance but produces a minimum amount or is free from undesirable smoke compounds.

Some filtration systems can selectively remove certain gas components, but no filter has yet been developed to remove selective particulate components. Tobacco and tobacco smoke contain thousands of compounds $(1,11,12)$, and their specific and individual roles make it difficult to establish a simple formula to judge leaf quality and usability. Such a change in the basic concept by no means indicates that the quality factors as previously described can be overlooked. It does indicate, however, the complexity of the problems facing all tobacco scientists.

There are two major schools of thought in approaching this task. In the United States, the general preference appears to be for reduction in both nicotine and tar levels in cigarette smoke as long as they meet consumer acceptance. In many other countries, especially in the United Kingdom, a proper tar/nicotine ratio is considered important, and a certain nicotine level must be maintained. For example, it has been suggested that the nicotine content in smoke should not be reduced below $1 \mathrm{mg}$ per cigarette.

It appears proper here to distinguish the terms "tar" and "total particulate matter (TPM)". TPM is the material trapped on a standard Cambridge filter upon smoking cigarettes under specified conditions. "Tar" is the weight of TPM minus nicotine and water.

Considering the numerous factors in tobacco production that affect leaf characteristics, the many variables in the formation of smoke components, and the quality and usability problems, obviously there is no easy solution to satisfy all the requirements. Our approadh is to isolate and identify desirable and undesirable characteristics in leaf tobacco with respect to quality and usability, and then to select certain "markers" for the construction of a theoretical model. Plant scientists will use this model as a basic reference for developing a more desirable leaf tobacco through various means of manipulation. One has to bear in mind that this approach is rather new, and that this "Theoretical Model $I^{\prime \prime}$ is based on findings from a limited number of well prepared samples which were subjected to extensive leaf, smoke and bioassay studies.

\section{LEAF CHARACTERISTICS AND SMOKE CONSTITUENTS}

Physical and chemical characteristics of leaf tobacco are related to each other. For example, the rates of leaf burn and filling values are positively correlated with cellulose, crude fiber, petroleum ether extract, and total volatile acids, and are negatively correlated with total $\mathrm{N}$, total reducing sugars, and total volatile bases (13). Leaf burn, especially degree of completeness in combustion, is an important quality factor affecting smoke constituents. Many factors are related to the duration of glow. Generally, $\mathrm{K}$ is positively related to burn, $\mathrm{Ca}$ und $\mathrm{P}$ appeared to be neutral, while $\mathrm{Cl}, \mathrm{S}, \mathrm{Mg}$, and total $\mathrm{N}$ in decreasing order are negatively related to duration of glow (1). Attoe (14) provided the following equation:

Log burn in seconds $=-0.009+0.583 \mathrm{~A}+0.473 \mathrm{~A}^{2}$, where $\mathrm{A}=$ $0.913+0.295 \times \% \mathrm{~K}_{2} \mathrm{O}-0.431 \times \% \mathrm{~N}-0.354 \times \mathrm{Cl}$.

The position of tobacco leaves on a stalk greatly affects the delivery of TPM as well as other smoke constituents $(15,16)$. Correlation and multiple regression among many leaf dharacteristics and smoke constituents were determined for several bright tobacco varieties (16). In addition to stalk position and other variables as described above, wax, polyphenols, phytosterols, petroleum ether extracts, nicotine, oxalate, sugar, and several amino acids may be used as a basis to estimate the levels of TPM and other smoke constituents in bright type tobacco $(1,15,16)$. In doing so, one has to exercise caution because of many other factors involved (static burning rate, pressure drop, transfer rate, pyrolysis, and filtration), to arrive at a reasonable interpretation. However, evidence demonstrated clearly that the higher the leaf position on a stalk, the less the filling value and combustibility, and the greater the $\mathrm{pH}$ value, TPM, nicotine, $\mathrm{HCN}$, volatile phenols, and polynuclear aromatic hydrocarbons (PAH) of the main stream smoke. $\mathrm{CO}_{2}$, acetaldehyde, and acrolein concentrations are highest in the smoke from leaves in the middle stalk positions (17). Leaf stalk position actually reflects the physical and chemical characteristics of the leaf and in most cases also reflects the degree of leaf maturity.

Although detailed data on burley and other tobacco types are not yet available, it is expected that leaf physical and chemical characteristics will influence smoke constituents following the general pattern as described above. However, plant genotype, cultural, and curing methods differ among tobacco types, and especially between bright and burley. These basic differences contribute to the variation of smoke constituents and thus affect the relative leaf usability. Because U. S. cigarettes are blended with bright, burley, Maryland, and Oriental types, the problems of quality and usability in these blends are more complex than in those cigarettes made of one tobacco type.

\section{LEAF CHARACTERISTICS AND EXPERIMENTAL BIOLOGICAL, RESPONSE}

More than 1,500 compounds have already been identified in tobacco and tobacco smoke. There are indi- 
cations that these compounds are merely a small fraction of the total components. In the semivolatile fraction of tobacco smoke, 30,000 "signals" were found by capillary gas chromatography. One cannot expect to identify all constituents present in tobacco or to examine their individual quality or biological significance in smoke.

Many reports associate certain smoke constituents to biological response, especially tumorigenicity on experimental animals (11). The most extensive studies were sponsored by the Tobacco Working Group (TWG), National Cancer Institute (NCI), involving many variables such as leaf material, manufacturing techniques, reconstitution, additives, filtration, and tobacco substitutes. These experimental cigarettes were evaluated extensively for leaf and smoke characteristics and biological response of experimental animals to the smoke. Results of these tests are being prepared for publication (18).

Discussion here will primarily be centered on leaf characteristics as they relate to tumor rate on experimental animals, with part of the raw data from the above sources and part from several related USDA* studies $(16,17,19)$. Because of the wide variability of the test materials involved in different experiments, one can develop only general and preliminary information from the available data.

Among the chemical components examined, nicotine, total volatile bases (TVB), phytosterols, polyphenolic compounds, petroleum ether extracts, waxes, lipid residues, and certain organic and fatty acids showed positive associations with tumor rate on test animals. Most of these leaf components are more concentrated in leaf lamina than in the midrib (stem). Nitrate, potassium, and cellulose were negatively associated with the tumor rate, and concentrations of these components are usually higher in stems than in leaf lamina. The latter group of components are also higher in reconstituted sheets than in natural leaf tobacco.

Nicotine appeared to be dominant as an indicator associated with experimental tumor rate based on observations from these tests. More studies are needed to clarify the exact nature of this most characteristic compound.

We also attempted to estimate the probability of relative tumor rate of experimental animals with several selected leaf characteristics excluding nicotine. The prediction equation is as follows:

Probability of experimental animals with tumor $=$

$$
\begin{aligned}
& 18.69 \text { (constant) } \\
& +0.742 \times \% \text { total phytosterols } \\
& -0.162 \times \text { ratio of wax in leaf/TPM in smoke } \\
& +0.0465 \times \% \text { petroleum ether extracts } \\
& -0.3788 \times \% \text { waxes } \\
& +0.204 \times \% \text { total polyphenols }
\end{aligned}
$$

$\mathrm{R}^{2}=0.851$.

\footnotetext{
* United States Department of Agriculture.
}

Because the total number of tests completed so far is still limited, one needs to exercise special caution to avoid overgeneralization in applying this information to all conditions. Some of these components may indeed serve as precursors of tumorigenic components in experimental animals, and some of them may be only indicators of other factors yet to be identified.

\section{SELECTED MARKERS OF LEAF QUALITY AND USABILITY}

Available information indicates clearly that many leaf characteristics that are desirable for tobacco quality may not be desirable for tobacco usability. Table 1 lists some selected leaf characteristics in relation to smoke quality and usability. Most of the quality factors are primarily based on available information from bright type tobacco.

Among the botanical characteristics, trichome number actually reflects differences in plant variety and stalk position. The "essential oils" that are responsible for leaf aroma are believed to be generated from the glandular trichomes, but there are reports to the contrary (20). Leaf shape reflects the stem/lamina ratio. A narrow leaf has a higher stem/lamina ratio than a broad leaf. When the stem is fully returned for cigarette manufacture, leaf shape or the relative amount of stem incorporated into a cigarette becomes an important factor affecting tobacco usability.

Among physical characteristics, there are some common factors for both quality and usability. These factors include proper leaf thickness (neither chaffy nor heavy), good filling value, and combustibility.

Chemical characteristics are of special interest in selecting markers. Chemical markers that are not desirable for either quality or usability include phytosterols, fatty acids, TVB, $\alpha$-amino $N$, free amino acids, other nitrogenous compounds, starch, and citric acid. Markers which are desirable for both quality and usability are nitrate and potassium. Among those components that are not desired for tobacco usability but are favored for leaf quality are sugars, polyphenols, petroleum ether extracts (PEE), lipid residue, waxes, resins, and possibly carbonyls. Several other components are yet to be evaluated.

Nicotine is the compound that needs further critical evaluation. It provides physiological satisfaction to the consumers, but it has adverse effects in tobacco usability. One may establish a marginal nicotine level that satisfies the consumer but contributes little adverse effect. For example, a level between 1.0 and $1.2 \mathrm{mg}$ nicotine per cigarette in the smoke would probably be acceptable to current consumers. If we consider factors such as pyrolysis, filtration, rate of transfer and loss in side stream, this would require a leaf tobacco of about $1.5 \%$ nicotine level. However, the constant reduction of nicotine in commercial cigarettes during the past two decades suggests that consumers may gradually be accustomed to accept as satisfactory a still lower amount of nicotine in the years to come. 
Table 1. Selected leaf characteristics in relation to smoke quality and usablilty.

\begin{tabular}{|l|l|l}
\hline Quality* & Usability & Major association (within a variety)
\end{tabular}

\section{Botanical:}

Trichome no.

Stem/lamina ratio

$+\quad-\quad+$

Physical:

Thickness

Filling value

Combustibility

$\begin{array}{ll}- & + \\ + & +\end{array}$

\section{Chemical:}

Nicotine

Total volatile bases (TVB)

Nitrate

$\alpha$-amino $N$

Total free amino acids

Other $\mathrm{N}$-compounds

Sugars

Starch

Oxalic acid

Malic acid

Citric acid

Succinic acid

$\mathrm{K}$

Ash (total)

Cell membrane substances

Polyphenol

Petroleum ether extract

Lipid residue

Waxes

Resins

Phytosterols

Fatty acids

Carbonyls

$\begin{array}{ll} \pm & - \\ + & + \\ - & = \\ \bar{t} & \overline{-} \\ \pm & \overline{-} \\ + & + \\ ? & + \\ \bar{?} & + \\ + & + \\ \pm & + \\ \overline{+} & + \\ + & - \\ + & - \\ + & - \\ + & - \\ \overline{+} & = \\ + & -\end{array}$

Stalk position, maturity

Leaf shape, stalk position

Stalk position, culture

Maturity, stalk position

Fertilizer, stalk position

Fertilization, stalk position, maturity

Fertilization, stalk position, maturity

Fertilization, stalk position

Maturity, curing

Maturity, curing

Fertilization, stalk position

Maturity, curing

Maturity, curing

Maturity, stalk position

Maturity, curing, stalk position

Maturity, curing, stalk position

Maturity, curing, stalk position

Fertilizer, stalk position

Fertilizer, stalk position

Stalk position, maturity

Stalk position, maturity, curing

Maturity, stalk position, curing

Maturity, stalk position, curing

Maturity, stalk position, curing

Maturity, stalk position, curing

Maturity, stalk position, curing

Maturity, curing

Maturity, curing

"Primarlly from studies of bright tobacco, "+" Indicates desirable, and "-" indicates undesirable. Most of these markers may be applicable to other tobacco types.

\section{A PRELIMINARY THEORETICAL MODEL AND "USABILITY INDEX"}

This preliminary model, "Theoretical Model I", consists of selected markers based on information currently available. Emphasis is placed on the tobacco usability, especially on factors related to tumorigenicity of test animals. Markers on other biological effects will be considered in later models.

Markers involved in this model are used to establish a "usability index". A higher emphasis is placed on chemical constituents. Physical factors are next in importance, because of the fact that they can be improved through reconstitution. Botanical factors are considered in this index only when natural leaf is used and entire stems are returned for cigarette manufacture.

1. If only chemical constituents are considered:

$$
\text { usability index }=\frac{\mathrm{A}}{\mathrm{B}} \text {. }
$$

2. If chemical, physical and botanical characteristics are considered:

$$
\text { usability index }=\frac{A}{B}+\frac{C+D}{E},
$$

where

$A=$ nitrate $+K+$ total ash + cellulose,

$\mathrm{B}=$ nicotine + TVB $+\alpha$-amino $\mathrm{N}+$ starch + polyphenols + PEE + lipid residues + waxes + phytosterols + fatty acids,

$\mathrm{C}=$ filling value + combustibility,

$\mathrm{D}=$ stem/lamina ratio,

$\mathrm{E}=$ thickness.

Employing this usability index, we examined several selected samples from two sets of tests that had available bioassay results. Table 2 shows results of samples including Kentucky reference cigarettes IRI, $\mathrm{NCI}^{*}$ standard experimental blend I (SEB-I), lamina

- National Cancer Institute. 
Table. 2. Calculated usability Index from first group of experimental clgarettes.

\begin{tabular}{|c|c|c|c|c|c|c|}
\hline & \multirow{2}{*}{$\begin{array}{c}\text { Kentucky } \\
\text { IRI }\end{array}$} & \multirow{2}{*}{ NCl SEB-I* } & \multicolumn{2}{|c|}{ NCI SEB-I } & \multicolumn{2}{|c|}{ Reconstituted SEB-I } \\
\hline & & & Lamina only & Stems only & $a$ & b \\
\hline \multicolumn{7}{|l|}{ 1. Factors "A" } \\
\hline $\begin{array}{l}\text { Nitrate } \mathbf{N}(\%) \\
\mathrm{K}(\%) \\
\text { Total ash }(\%) \\
\text { Cellulose }(\%)\end{array}$ & $\begin{array}{r}0.26 \\
4.12 \\
16.70 \\
35.21\end{array}$ & $\begin{array}{r}0.32 \\
4.50 \\
17.00 \\
34.80\end{array}$ & $\begin{array}{r}0.02 \\
3.45 \\
15.62 \\
32.43\end{array}$ & $\begin{array}{r}0.07 \\
9.16 \\
21.57 \\
41.99\end{array}$ & $\begin{array}{r}0.40 \\
4.45 \\
15.88 \\
47.08\end{array}$ & $\begin{array}{r}0.35 \\
4.45 \\
18.10 \\
43.29\end{array}$ \\
\hline Total "A" & 56.29 & 56.62 & 51.52 & 72.79 & 67.81 & 66.19 \\
\hline \multicolumn{7}{|l|}{ 2. Factors "B" } \\
\hline 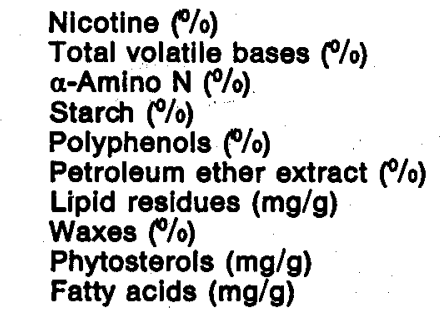 & $\begin{array}{r}2.43 \\
0.50 \\
0.24 \\
3.52 \\
4.62 \\
5.73 \\
72.00 \\
0.26 \\
1.90 \\
3.82\end{array}$ & $\begin{array}{r}2.38 \\
0.50 \\
0.25 \\
3.63 \\
4.60 \\
5.14 \\
60.50 \\
0.17 \\
1.98 \\
3.05\end{array}$ & $\begin{array}{r}2.86 \\
0.52 \\
0.23 \\
3.30 \\
4.64 \\
6.37 \\
75.89 \\
0.28 \\
2.14 \\
5.16\end{array}$ & $\begin{array}{r}0.50 \\
0.21 \\
0.18 \\
5.70 \\
1.11 \\
0.77 \\
10.85 \\
0.04 \\
0.76 \\
1.80\end{array}$ & $\begin{array}{r}1.57 \\
0.35 \\
0.23 \\
4.85 \\
3.03 \\
2.50 \\
27.98 \\
0.04 \\
1.07 \\
1.44\end{array}$ & $\begin{array}{r}1.99 \\
0.45 \\
0.24 \\
5.90 \\
3.93 \\
4.23 \\
55.37 \\
0.17 \\
1.78 \\
0.92\end{array}$ \\
\hline Total "B" & 95.02 & 82.20 & 101.39 & 21.92 & 43.06 & 74.93 \\
\hline Usability index & 0.59 & 0.69 & 0.50 & 3.32 & 1.57 & 0.88 \\
\hline
\end{tabular}

- National. Cancer Institute standard experimental blend I.

only or stem only from SEB-I, and two different reconstituted sheets from SEB-I. The usability index generally agrees with the results of experimental animal tumor rate from test group I. Table 3 shows another set of samples from the second group $\mathrm{NCI}$ experimental cigarettes, which includes, in addition to IRI, SEB-I and SEB-II, two tobacco types and two substitute smoking materials. The usability indexes also demonstrated a generally similar trend as shown from ex- perimental animal results, except that in two tobacco substitute materials the index numbers were too high to have meaningful comparisons with natural tobacco products. The composition of non-tobacco materials (substitutes) differed widely from that of normal leaf tobaccos.

We do not have data on physical markers of experimental cigarettes that had long-term bioassay results. A usability index with both chemical and

Table 3. Calculated usablilty Index from second group of experimental clgarettes.

\begin{tabular}{|c|c|c|c|c|c|c}
\hline $\begin{array}{c}\text { Kentucky } \\
\text { IRI }\end{array}$ & $\begin{array}{c}\text { NCI } \\
\text { SEB }\end{array}$ & $\begin{array}{c}\text { NCI } \\
\text { SEB-II }\end{array}$ & $\begin{array}{c}\text { Burley } \\
\text { (Low- } \\
\text { Nicotine } \\
\text { Straight) }\end{array}$ & $\begin{array}{c}\text { Bright } \\
\text { (Low- } \\
\text { Nicotine } \\
\text { Straight) }\end{array}$ & $\begin{array}{c}\text { Substitute } \\
\text { material }\end{array}$ & $\begin{array}{c}\text { Substitute } \\
\text { material }\end{array}$ \\
\hline
\end{tabular}

\section{Factors "A"}

\begin{tabular}{lrrrrrrr} 
Nitrate N (\%) & 0.06 & 0.12 & 0.12 & 0.46 & 0.04 & 0.00 & 0.04 \\
K (\%) & 3.90 & 4.10 & 4.25 & 5.10 & 4.00 & 0.00 & 0.00 \\
Total ash (\%) & 12.95 & 13.22 & 13.25 & 20.21 & 13.58 & 32.55 & 52.76 \\
Cellulose (\%) & 34.60 & 37.00 & 35.38 & 33.78 & 34.67 & 0.00 & 11.20 \\
\hline Total "A" & 51.51 & 54.44 & 53.00 & 59.55 & 52.29 & 32.55 & 64.00 \\
\hline
\end{tabular}

\section{Factors "B"}

Nicotine $(\%)$

Total volatile bases $(\%)$

a-Amino $\mathrm{N}(\%)$

Starch $(\%)$

Polyphenols $(\%)$

Petroleum ether extract $(\%)$

Lipid residue $(\mathrm{mg} / \mathrm{g}$ )

Waxes $(\%)$

Phytosterols (mg/g)

Fatty acids $(\mathrm{mg} / \mathrm{g})$

$$
\begin{aligned}
& 1.93 \\
& 0.41 \\
& 0.23 \\
& 0.34 \\
& 4.37 \\
& 5.10 \\
& 7.69 \\
& 0.27 \\
& 2.03 \\
& 5.21
\end{aligned}
$$

Total "B" 27.58

Usability index

\begin{tabular}{|c|}
1.93 \\
0.41 \\
0.23 \\
0.34 \\
4.37 \\
5.10 \\
7.69 \\
0.27 \\
2.03 \\
5.21 \\
\hline 27.58 \\
\hline 1.87
\end{tabular}

\begin{tabular}{rrr}
1.93 & 1.79 & 0.18 \\
0.42 & 0.44 & 0.21 \\
0.15 & 0.21 & 0.15 \\
0.38 & 0.32 & 0.06 \\
4.40 & 3.68 & 0.60 \\
5.06 & 4.52 & 5.54 \\
8.53 & 7.19 & 8.01 \\
0.41 & 0.30 & 0.38 \\
2.16 & 1.85 & 1.84 \\
6.28 & 6.54 & 2.35 \\
\hline 29.72 & 26.84 & 19.32 \\
\hline 1.83 & 1.97 & 3.08 \\
\hline
\end{tabular}

\begin{tabular}{l}
0.46 \\
0.28 \\
0.25 \\
0.34 \\
3.87 \\
8.71 \\
7.51 \\
0.40 \\
3.28 \\
6.58 \\
\hline 31.68 \\
\hline 1.65 \\
\hline
\end{tabular}

\begin{tabular}{ll}
0.06 & 0.04 \\
0.08 & 0.06 \\
0.02 & 0.11 \\
0.30 & 0.00 \\
0.04 & 0.13 \\
0.09 & 0.16 \\
0.48 & 0.44 \\
0.05 & 0.06 \\
0.03 & 0.06 \\
0.15 & 0.34 \\
\hline 1.30 & 1.40 \\
\hline 25.03 & 45.71 \\
\hline
\end{tabular}

\footnotetext{
- National Cancer Institute standard experimental. blend.
} 
physical markers may be more dependable than that calculated with chemical markers only.

Is is evident that such a simple index formula may not be satisfactory because it places equal weights on all selected chemical markers, and it does not take into consideration possible interactions among these markers. To correct this condition, multiple regressions are computed with selected markers as " $X$ " variables, and biological response (" $P_{t}^{\prime \prime}$-proportion of animals surviving without tumor) as " $Y$ " variable. Severa] equations for prediction of $P_{f}$-values are listed as follows:

1. Based on results from test $I\left(R^{2}=0.82\right)$ :

$$
\begin{aligned}
P_{t} & =1.5093 \\
& -4.408 \times \text { total volatile bases }(\%) \\
& +0.304 \times \text { nicotine }(\%) \\
& +0.323 \times \text { nitrate } \mathrm{N}(\%) \\
& -0.050 \times \mathrm{K}(\%) \\
& +0.004 \times \text { lipid residue }(\mathrm{mg} / \mathrm{g}) \\
& +1.302 \times \alpha \text {-amino } \mathrm{N}(\%)
\end{aligned}
$$

2. Based on results from test II, including all data from non-tobacco substitute materials $\left(R^{2}=0.88\right)$ :

$$
\begin{aligned}
P_{f} & =1.517 \\
& -0.161 \times \text { nicotine }(\%) \\
& -0.019 \times \text { ash }(\%) \\
& -0.018 \times \text { cellulose }(\%) \\
& +0.457 \times \text { nitrate } \mathrm{N}(\%) \\
& -0.045 \times \text { petroleum ether extracts }(\%) \\
& +0.144 \times \text { phytosterols }(\mathrm{mg} / \mathrm{g})
\end{aligned}
$$

3. Based on results from test II, excluding all data from non-tobacco substitute materials $\left(R^{2}=0.88\right)$ :

$$
\begin{aligned}
P_{1} & =0.1026 \\
& -0.134 \times \text { nicotine }(\%) \\
& +0.012 \times \text { cellulose }(\%) \\
& +0.474 \times \text { starch }(\%) \\
& +0.525 \times \text { nitrate } N(\%) \\
& -0.397 \times \text { total volatile bases }(\%) \\
& +0.556 \times \alpha \text {-amino } N(\%)
\end{aligned}
$$

These three regression equations include most variables we selected as markers in the Theoretical Model I except polyphenols, waxes, and fatty acids. Waxes and fatty acids may be considered as a part of the PEE fraction, and polyphenols appear to have less weight among those markers selected.

\section{APPROACHES TO}

\section{THE THEORETICAL MODEL}

The suggested Theoretical Model I, as demonstrated by the usability index or markers, can serve as a basis for plant scientists to improve tobacco usability. The elements of such a model can be gathered with two concurrent approaches: [a] breeding; selection and culture, and [b] homogenized leaf curing (HLC) and reconstitution.

\section{a. Breeding, Selection and Culture}

In our collection of Nicotiana germplasm, there are about 1,600 entries. These include tobacco introductions from various parts of the world, established varieties and breeding lines, and all Nicotiana species. These resource materials are being screened for selected markers. To obtain a safer tobacco by combining these selected markers into one plant will primarily depend on conventional breeding and parasexual hybridization. Culture changes to improve these factors are also being examined and show considerable potential. These include modifications in fertilization, spacing (such as high density planting), topping, and physiological control of leaf maturity. Detailed discussions have been presented in a separate publication (21).

\section{b. Homogenized Leaf Curing (HLC) and Reconstitution}

HLC process has demonstrated vast opportunities for improving tobacco utilization. During homogenization, incubation, and dehydration, one can control the biochemical changes toward a favorable direction. More important, there are redistributions of leaf components which, under conventional curing, are not possible. The essential plant components that are considered unfavorable can be removed if necessary by extraction while the plant material is in a slurry. In addition, favorable factors may be incorporated during reconstitution to improve chemical as well as physical properties. Preliminary results show the desirability of such an approach (22).

\section{SUMMARY}

A changing concept in recent years on the usability of tobacco leaf has introduced many problems that may not fit the traditional requirements of leaf quality. Usability represents the state of being usable without adverse effects to consumers. Theoretical Model I with selected markers is proposed for the development of tobacco materials with emphasis on improving tobacco usability. This preliminary Model I is based on currently available data, and can be improved as new information becomes available.

Plant scientists may use this model to develop leaf tobacco of improved usability either through breeding, selection, and culture, or by means of homogenized leaf curing and reconstitution.

\section{ZUSAMMENFASSUNG}

Die sich seit einigen Jahren abzeichnende Veränderung in der Auffassung der Gebrauchseignung von Tabakblattgut hat zu vielen Problemen geführt, die nicht im Einklang stehen mit den Anforderungen, die üblicherweise an die Blattqualität gestellt werden. Die Brauchbarkeit bezeichnet die Eigenschaft, ohne für den Verbraucher abträgliche Wirkungen verwendet werden zu können. Das Theoretische Modell I mit ausgewählten Parametern wird in der vorliegenden Arbeit vorgeschla- 
gen mit dem Ziel, Tabakmaterial unter Betonung der Verbesserung der Gebrauchseignung zu entwickeln. Dieses vorläufige Modell I basiert auf gegenwärtig verfügbaren Daten und kann durch Anpassung an den jeweils neuen Informationsstand verbessert werden.

Pflanzenwissenschaftler können sich dieses Modells bedienen, um durch Züchtung, Selektion und Kulturbedingungen oder mit Hilfe des HLC-Verfahrens (homogenized leaf curing) und der Rekonstitution Blattgut von verbesserter Braudibarkeit zu entwidkeln.

\section{RESUME}

Ces dernières années, le changement dans la conception de la possibilité d'utilisation du tabac en feuilles a amené plusieurs problèmes qui peuvent être incompatibles avec les exigences traditionnelles quant à la qualité de la feuille. La possibilité d'utilisation est liée à l'utilisation sans effets nocifs pour le consommateur. Le Modèle Théorique I à base de qualités sélectionnées est proposé pour le développement de tabacs qui auraient une plus grande possibilité d'utilisation. Ce modèle préliminaire I est basé sur des données connues actuellement, et petut être amélioré au fur et à mesure des nouvelles informations.

Les spécialistes de plantation peuvent utiliser ce modèle pour développer une feuille de tabac plus utilisable, par reproduction, sélection et culture, ou par le séchage de feuilles homogénéisées (homogenized leaf curing / HLC) et reconstitution.

\section{REFERENCES}

I. Tso, T. C.: A physiology and biochemistry of tobacco plants; Dowden, Hutchinson and Ross, Inc., Stroudsburg, Pennsylvania, 1972, pp. 305-358.

2. Brüdkner, $H$.: The chemical determination of tobacco quality (Die Biochemie des Tabaks); Paul Parey, Berlin, 1936, pp. 296-300.

3. Pyriki, C.: Relations between the demical composition of tobacco and the haracteristics of smoke; Proc. Second International Sci. Tobacco Congress, Brussels, 1958, pp. 460-495.

4. Coulson, D. A.: Tobacco quality; Tobacco Workers' Conference, Athens, Georgia, 1958.

5. Weybrew, J. A., and R. L. Stephens: Survey of the carbonyl content of tobacco; Tobacco Science 6 (1.962) 53-57.

6. Weybrew, J. A., and L. A. Jones: The elaboration of carbonyls by tobacco during growth and fuecuring; Tobacco Science 6'(1962) 164-166.

7. Swain, A. P., R. F. Petterson, Jr., and R. L. Stedman: Composition studies on tobacco, XXI. The headspace vapours of leaf; J. Sci. Food Agr. 17 (I966) 349 .

8. Griffith, R. B., R. R. Johnson and A. D. Quinn: Cigarette flavor treatments; U. S. Patent $2,174,485$, March 23, 1965.

9. Stedman, R. L., and C. D. Still: Flavor contribution of Turkish tobacco in blended cigarettes; USDA Report 73-43, Washington, D. C., $x 964$.
10. U. S. Department of Health, Education, and Welfare, Public Health Service: Smoking and health, Report of the Advisory Committee to the Surgeon General of the Public Health Service; PHS Publ. 1964, \#1103, U. S. Government Printing Office, Washington, D. C., 20402.

11. Wynder, E. L., and D. Hoffmann: Tobacco and tobacco smoke; Academic Press, New York, New York, 1967.

12. Stedman, R. L.: The chemical composition of tobacco and tobacco smoke; Chem. Rev. 68 (1968) 153-207.

13. United States Department of Agriculture (USDA): Statistical analysis of tobacco data; Agriculture Marketing Service Tech. Res. Paper 1-4, 1958.

14. Attoe, $O$. J.: Leaf burn of tobacco as influenced by content of potassium and chlorine; J. Agro. $3^{8}$ (1946) $186-196$.

15. Tso, T. C., and G. B. Gori: Effect of tobacco characteristics on cigarette smoke composition, in: The chemistry of tobacco and tobacco smoke, Edi. 1. Schmeltz; Plenum Press, New York, 1972.

16. Tso, T. C., G. Rathkamp, and D. Hoffmann: Chemical studies on tobacco smoke, XXI: Correlation and multiple regression among selected cigarette smoke constituents and leaf characteristics of bright tobacco; Beiträge zur Tabakforschung 7 (1973) 190-194.

17. Rathkamp, G., T. C. Tso, and D. Hoffmann: Chemical studies on tobacco smoke, XX: Smoke analysis of cigarettes made from bright tobaccos differing in variety and stalk positions; Beiträge zur Tabakforshung 7 (1973) 179-189.

18. National Cancer Institute, Bethesda, Maryland: Toward less hazardous cigarettes / The first set of experimental cigarettes; Report No. 1, in press.

19. Tso, T. C., J. F. Chaplin, and others: Leaf characteristics, smoke constituents, and biological response of bright type tobaccos; Agricultural Research Service, United States Department of Agriculture, in preparation.

20. Barrera, R., and E. A. Wernsman: Trichome type, density, and distribution on the leaves of certain tobacco varieties and hybrids; Tobacco Science 10 (1966) 157-161.

21. Tso, T. C.: The potential for producing safer cigarette tobacco; Agr. Science Review 1o (3) (1972) $\mathbf{I}-\mathbf{I} \mathbf{0}$.

22. Tso, T. C., R. Lowe, and D. W. DeJong: Homogenized leaf curing, I. Theoretical basis and some preliminary results; Beiträge zur Tabakforschung 8 (1975) 44-51.

The authors' address:

T. C. Tso: US Department of Agriculture, Agricultural Research Service, Northeastern Region, Agricultural Research Center, Beltsville, Maryland, 20705, USA.

G. B. Gori: National Cancer Institute, US Department of Health, Education, and Welfare, Bethesda, Maryland, 20014, USA. 